\title{
p75 Neurotrophin Receptor Expression Defines a Population of BDNF-Responsive Neurogenic Precursor Cells
}

\author{
Kaylene M. Young, ${ }^{1,2}$ Tobias D. Merson, ${ }^{3}$ Areechun Sotthibundhu, ${ }^{1}$ Elizabeth J. Coulson, ${ }^{1 *}$ and Perry F. Bartlett ${ }^{1 \star}$ \\ ${ }^{1}$ Queensland Brain Institute, The University of Queensland, Brisbane QLD 4072, Australia, ${ }^{2}$ The Walter and Eliza Hall Institute for Medical Research, \\ Melbourne VIC 3050, Australia, and ${ }^{3}$ Howard Florey Institute, The University of Melbourne, Melbourne VIC 3010, Australia
}

\begin{abstract}
Although our understanding of adult neurogenesis has increased dramatically over the last decade, confusion still exists regarding both the identity of the stem cell responsible for neuron production and the mechanisms that regulate its activity. Here we show, using flow cytometry, that a small population of cells $(0.3 \%)$ within the stem cell niche of the rat subventricular zone (SVZ) expresses the p75 neurotrophin receptor ( $\mathrm{p} 75^{\mathrm{NTR}}$ ) and that these cells are responsible for neuron production in both newborn and adult animals. In the adult, the p75 ${ }^{\mathrm{NTR}}$-positive population contains all of the neurosphere-producing precursor cells, whereas in the newborn many of the precursor cells are p $75^{\text {NTR }}$ negative. However, at both ages, only the neurospheres derived from p $75^{\text {NTR }}$-positive cells are neurogenic. We also show that neuron production from $\mathrm{p} 75^{\mathrm{NTR}}$-positive but not $\mathrm{p} 75^{\mathrm{NTR}}$-negative precursors is greatly enhanced after treatment with brain-derived neurotrophic factor (BDNF) or nerve growth factor. This effect appears to be mediated specifically by $\mathrm{p} 75^{\mathrm{NTR}}$, because precursor cells from p $75^{\mathrm{NTR}}$-deficient mice show a 70\% reduction in their neurogenic potential in vitro and fail to respond to BDNF treatment. Furthermore, adult p75 ${ }^{\mathrm{NTR}}$-deficient mice have significantly reduced numbers of PSA-NCAM (polysialylated neural cell adhesion molecule)-positive SVZ neuroblasts in vivo and a lower olfactory bulb weight. Thus, $\mathrm{p} 75^{\mathrm{NTR}}$ defines a discrete population of highly proliferative SVZ precursor cells that are able to respond to neurotrophin activation by increasing neuroblast generation, making this pathway the most likely mechanism for the increased neurogenesis that accompanies raised BDNF levels in a variety of disease and behavioral situations.
\end{abstract}

Key words: subventricular zone (SVZ); BDNF; stem cell; neurotrophin; 75 neurotrophin receptor (p75 ${ }^{\mathrm{NTR}}$ ); neurogenesis

\section{Introduction}

Mounting evidence suggests that postnatal neurogenesis is strongly influenced by environment (Kempermann et al., 1998; Gould et al., 2000), behavior (van Praag et al., 1999; Farmer et al., 2004), and conditions such as Alzheimer's disease, Huntington's disease, depression, seizure, and stroke (Kempermann, 2002; Curtis et al., 2003; Felling and Levison, 2003; Jin et al., 2004; Zhang et al., 2004; Hagihara et al., 2005). One of the more widely studied regions, which contains stem cells that respond to external stimuli by producing neurons, is the subventricular zone (SVZ) (Rochefort et al., 2002). However, a lack of knowledge about the growth factor receptor repertoire of the stem cells has hampered research linking external neurogenic stimuli with their molecular mediators.

In a previous study, we performed a gene microarray screen of SVZ stem cells isolated using a negative selection criterion (Rietze et al., 2001). This analysis revealed expression of the panneurotrophin receptor $\mathrm{p} 75$ (p75 ${ }^{\mathrm{NTR}}$ ) in the stem cell population.

\footnotetext{
Received Oct. 6, 2005; revised March 30, 2007; accepted March 30, 2007.

This work was supported by the National Health and Medical Research Council of Australia and the Motor Neurone Disease Research Institute of Australia. A.S. is a recipient of a Development and Promotion of Science and Technology Talent Scholarship (Mahidol University, Salaya, Thailand). We thank Dr. Tara Walker for advice on quantitative PCR experiments and Rowan Tweedale for editorial assistance.

${ }^{*}$ E.J.C. and P.F.B. contributed equally to this work.

Correspondence should be addressed to Perry F. Bartlett, Queensland Brain Institute, The University of Queensland, Brisbane QLD 4072, Australia. E-mail: p.bartlett@uq.edu.au.

DOI:10.1523/JNEUROSCI.0654-07.2007

Copyright $\odot 2007$ Society for Neuroscience $\quad$ 0270-6474/07/275146-10\$15.00/0
}

p75 ${ }^{\text {NTR }}$ is best known for its role in modulating postmitotic neural cell survival decisions (Coulson et al., 1999; Dechant and Barde, 2002; Roux and Barker, 2002). It is highly expressed during development of the nervous system but is downregulated postnatally in most brain areas. However, some cells in the SVZ, which appear to be immature and mitotically active (Giuliani et al., 2004), continue to express significant levels of p $75^{\text {NTR }}$ throughout adulthood (Yan and Johnson, 1989; Calza et al., 1998; Giuliani et al., 2004). Although p $75^{\mathrm{NTR}}$-mediated signals have been shown to regulate proliferation and differentiation of neural and non-neural cells in vitro (Cattaneo and McKay, 1990; Seidl et al., 1998; Chittka and Chao, 1999), and p75 ${ }^{\text {NTR }}$ expression in the SVZ can increase during periods of in vivo adult stem cell activity (Calza et al., 1998), the function of these SVZ cells and the role that $\mathrm{p} 75^{\mathrm{NTR}}$ plays in their regulation has not been reported.

One ligand for $\mathrm{p} 75^{\mathrm{NTR}}$, brain-derived neurotrophic factor $(\mathrm{BDNF})$, is also upregulated in response to a wide variety of neurogenic stimuli and has been linked with increased neuron generation and neuroblast migration from the SVZ to the striatum (Pencea et al., 2001; Chmielnicki et al., 2004) and olfactory bulb (Zigova et al., 1998; Benraiss et al., 2001). Although BDNFstimulated neurogenesis has been implicated in the positive neurogenic effects of antidepressant drugs (Kempermann, 2002; Hashimoto et al., 2004), dietary restriction (Lee et al., 2002) and exercise (Adlard and Cotman, 2004; Garza et al., 2004), the mechanism of this regulation remains elusive. 
Based on the above lines of evidence, we hypothesized that p $75^{\mathrm{NTR}}$-positive cells in the SVZ might be BDNF-responsive, neurogenic precursor cells. We report here that $\mathrm{p} 75^{\mathrm{NTR}}$ defines a population of neurosphere-forming precursor cells that persists in the SVZ from birth into adulthood. Furthermore, we demonstrate that $\mathrm{p} 75^{\mathrm{NTR}}$-positive precursors are neurogenic both in vitro and in vivo and that this neurogenesis is stimulated by neurotrophins.

\section{Materials and Methods}

Animals. All experiments were conducted in accordance with the Australian Code of Practice for the Care and Use of Animals for Scientific Purposes and with ethics approval from the Animal Ethics Committees of the Royal Melbourne Hospital and The University of Queensland.

Postnatal day 2 (P2) and adult (P100) Wistar rats were used throughout. p $75^{\mathrm{NTR}-1-}$ and $\mathrm{p} 75^{\mathrm{NTR}+/+}$ mice were derived from intercrossing heterozygous $75^{\text {NTR }}$ exon III-deficient parents (Lee et al., 1992) that had been backcrossed for $>10$ generations to C57BL/6 animals. Mice were genotyped as described previously (Yeo et al., 1997).

Neurosphere culture. Neurospheres were generated as a means of quantifying and retrospectively identifying neural stem cells. These cultures were generated by harvesting and dissociating the SVZ into a single-cell suspension and culturing the cells in proliferative neurosphere medium that contained epidermal growth factor (EGF; BD Biosciences, Sydney, Australia) and basic fibroblast growth factor (bFGF; Roche, Basel, Switzerland), as described previously (Rietze et al., 2001). Rat cultures were supplemented with $2 \%(\mathrm{v} / \mathrm{v})$ bovine serum albumin (BSA; Roche). These primary cells were plated into tissue culture plates at a density not exceeding 3500 cells $/ \mathrm{cm}^{2}$. At maturity $(\sim 120 \mu \mathrm{m}$ in diameter), neurospheres that had been plated at a density of 1 cell per well, confirmed by light microscopy $4 \mathrm{~h}$ after plating, were enzymatically dissociated to examine the stem cell characteristic of self-renewal. Dissociated cells were reseeded at a density not exceeding $10,000 \mathrm{cells} / \mathrm{cm}^{2}$. Alternatively, neurospheres were differentiated to examine the characteristic of multipotentiality. Whole clonally derived and equivalently sized neurospheres were transferred onto poly-ornithine-coated glass coverslips in mitogenfree medium containing $1 \%$ fetal bovine serum (FBS). The generation of neurons was assessed after differentiation for either 2 (postnatal) or 4 (adult) d. Neurosphere cells were allowed to differentiate for up to $7 \mathrm{~d}$ for quantification of oligodendrocytes. The statistical significance of differences in the numbers of differentiated cell types between genotypes was determined by $t$ tests.

Fluorescence-activated cell sorting. Fluorescence-activated cell sorting (FACS) purification of $\mathrm{p} 5^{\mathrm{NTR}}$-positive cells from the $\mathrm{P} 2$ and adult rat SVZ was performed to determine the identity of these cells. Tissue from five to eight P2 animals was pooled, and the cell suspension was incubated with mouse anti-rat p75 NTR (1:1000; Millipore, Melbourne, Australia) on ice for $45 \mathrm{~min}$ and then washed with mouse tonicity PBS containing $1 \%$ FBS. Anti-p $75^{\text {NTR }}$ binding was detected with biotinylated anti-mouse IgG (1:200; Vector Laboratories, Sydney, Australia) and phycoerythrin (PE)-conjugated streptavidin (1:200; BD Biosciences). Before sorting, the cells were passed through a $40 \mu \mathrm{m}$ cell strainer and rinsed with PBS containing $0.5 \mu \mathrm{g} / \mathrm{ml}$ propidium iodide to identify dead cells. Cells were sorted on a FACSVantage (BD Biosciences) with DIVA software. The sort profile was divided into p $75^{\mathrm{NTR}}$-high, $\mathrm{p} 75^{\mathrm{NTR}}$-mid, and p $75^{\mathrm{NTR}}$-negative cells based on the fluorescence of $\mathrm{p} 75^{\mathrm{NTR}}$-positive PC12 cells, SVZ cells stained without anti-rat p75 ${ }^{\mathrm{NTR}}$, and unstained SVZ cells, respectively. The three populations were collected into proliferative medium containing EGF, bFGF, and 0, 30, or $100 \mathrm{ng} / \mathrm{ml} \mathrm{BDNF}$ (Cytolab, Rehovot, Israel). Cells were plated into 96-well tissue culture plates in dilutions from 200 down to 1 cell per well (confirmed by counting 4 or $24 \mathrm{~h}$ after plating as indicated). After 5-7 d in culture, neurosphere formation was used as a read-out for proliferative activity and differences analyzed by ANOVA. Plating cell density did not influence the frequency of neurosphere formation.

Flow cytometric analysis was also performed to determine the number of polysialylated neural cell adhesion molecule (PSA-NCAM)-positive cells within the SVZ of individual adult $\mathrm{p} 75^{\mathrm{NTR}+/+}$ and $\mathrm{p} 75^{\mathrm{NTR}-1-}$ mice. The SVZ was dissociated as described previously for neurosphere cultures. The resultant single-cell suspension was stained with anti-PSANCAM (1:500; Millipore), detected with Alexa 633 goat anti-mouse IgM (1:700; Invitrogen, San Diego, CA), and counterstained with the cell viability dye 7-AAD (Invitrogen). Stained cell suspensions were then analyzed by flow cytometry to determine the number of PSA-NCAMpositive cells per 100,000 events. The average number of positive events in $\mathrm{p} 75^{\mathrm{NTR}-1-}$ suspensions was determined as a percentage of the average number of $\mathrm{p} 75^{\mathrm{NTR}+/+}$-positive events for each experiment $(n=4 \mathrm{ex}-$ periments, with $2-4$ animals per genotype per experiment). The difference was then compared by $t$ test.

Immunohistochemistry. To evaluate the expression of $\mathrm{p} 75^{\mathrm{NTR}}$ in the SVZ, brains from P2 and adult rats were prepared for immunohistochemistry by perfusion fixation with $4 \%$ paraformaldehyde (PFA) in PBS. Brains were removed and immersed overnight in fresh $4 \%$ PFA at $4^{\circ} \mathrm{C}$, followed by an additional $24 \mathrm{~h}$ in $20 \%$ sucrose. All brains were OCT (optimal cutting temperature) compound embedded and either cryosectioned to $10 \mu \mathrm{m}$ coronal sections and collected onto permafrost slides or cryosectioned to $30 \mu \mathrm{m}$ coronal sections and collected into PBS to stain as floating sections for confocal analysis.

For all immunostaining, antibodies were diluted in blocking solution [PBS, $2 \%$ normal goat serum (NGS), and $2 \%$ FBS], with $0.1 \%$ Triton $\mathrm{X}-100$ when permeabilization was required. The following antisera were used: mouse monoclonal anti-extracellular p75 ${ }^{\text {NTR }}$ antibody (1:1000; clone IgG192; Millipore); rabbit polyclonal anti-intracellular p75 ${ }^{\text {NTR }}$ (1: 200; Promega, Sydney, Australia); mouse anti- $\beta$-III-tubulin (1:200; Promega); mouse anti-NeuN (1:500; Millipore); mouse anti-S100 $\beta$ (1:500; Sigma, Sydney, Australia); guinea pig anti-Sox10 (1:2000; kindly gifted by Dr. Michael Wegner, Institute für Biochemie, Friedrich-Alexander Universität Erlangen-Nürnberg, Erlangen, Germany); mouse anti-PSANCAM (1:500; Millipore); guinea-pig anti-doublecortin (1:3000; Millipore); rabbit anti-glial fibrillary acidic protein (GFAP; 1:500; DakoCytomation, Carpinteria, CA); mouse anti-nestin IgG1 (1:10; Millipore); mouse anti-bovine O4 IgM (1:32; American Type Culture Collection, Manassas, VA); AlexaFluor 488-conjugated goat anti-mouse $\operatorname{IgG}(1: 700$; Invitrogen); AlexaFluor 488-conjugated goat anti-rabbit IgG (1:1000; Invitrogen); biotinylated anti-mouse IgG (1:200; Vector Laboratories); AlexaFluor 488-conjugated goat anti-mouse IgM (1:700; Invitrogen); AlexaFluor 568-conjugated goat anti-mouse IgM (1:1000; Invitrogen); AlexaFluor 568-conjugated goat anti-mouse IgG1 (1:700; Invitrogen); AMCA (7-amino-4-methylcoumarin-3-acetic acid)-conjugated goat-anti rabbit IgG (1:200; Jackson ImmunoResearch, West Grove, PA); cyanine 3 (CY3)-conjugated goat anti-guinea pig $\operatorname{IgG}$ (1:500; Millipore); and 4',6'-diamidino-2-phenylindole dihydrochloride (DAPI) nuclear stain (1:1000; DakoCytomation). Sections that had been treated with biotinylated anti-mouse IgG were also incubated with PE-conjugated streptavidin (1:200; BD Biosciences). All sections were coverslipped with fluoromount (DakoCytomation). Equivalent sections/cells were incubated without the primary antibody as negative controls.

Immunostaining of whole-mount adult SVZ. To examine the effect of p $75^{\text {NTR }}$ on adult neurogenesis in vivo, the number of PSA-NCAMpositive neuroblasts was examined in whole-mount preparations of the lateral wall of the lateral ventricle of p75 ${ }^{\mathrm{NTR}+/+}$ and $\mathrm{p} 75^{\mathrm{NTR}-1-}$ mice. Staining was performed as described by Merson et al. (2006). Briefly, mice were perfused with ice-cold saline, and the lateral walls of the lateral ventricles were dissected bilaterally before fixing with 3\% PFA, washing with $0.1 \mathrm{M}$ Tris-buffered saline (TBS; $\mathrm{pH} 7.5$ ), and immersing for $30 \mathrm{~min}$ in $-20^{\circ} \mathrm{C}$ methanol, followed by acetone. Preparations were rinsed with TBS/0.5\% Triton X-100 (TBST) and blocked with 10\% NGS/TBST before staining with anti-PSA-NCAM (1:500; Millipore) followed by biotinylated goat anti-mouse IgM (1:200; Vector Laboratories). Endogenous peroxidase activity was quenched with $0.3 \% \mathrm{H}_{2} \mathrm{O}_{2}$ in methanol, and staining was visualized with horseradish peroxidase (Vectastain Elite ABC Kit; Vector Laboratories) and 3'3'-diaminobenzidine tetrahydrochloride (Pierce, Rockford, IL). Photomicrographs were taken on a lowmagnification stereomicroscope, and the number of black pixels per trace was quantified using ImageJ software (http://rsb.info.nih.gov/ij/), without concurrent knowledge of genotype. The difference in the number of pixels between genotypes was compared by $t$ test. 
Olfactory bulb analysis. Brains from $\mathrm{p} 75^{\mathrm{NTR}+/+}$ and $\mathrm{p} 75^{\mathrm{NTR}-1-}$ mice at P2 $(n=7), 7$ weeks $(n=5)$, or 10 months $(n=8)$ of age were dissected and weighed to determine total brain weight. The olfactory bulbs were subsequently dissected and weighed separately. Comparisons of individual olfactory bulb weights were made between age and genotype by ANOVA.

PCR. Total RNA was generated from sorted cell populations using the Absolutely RNA Nanoprep kit (Stratagene, Sydney, Australia). RNA for control samples was generated from PC12 cells (American Type Culture Collection) and P2 rat brainstem using the RNeasy kit (Invitrogen, Melbourne, Australia) according to the manufacturer's instructions. The cDNA was synthesized using Superscript III reverse transcriptase (Invitrogen), following the method outlined by the manufacturer. Two microliters of the resulting cDNA were used directly in the PCR.

Primer sequences specific to individual members of the neurotrophin receptor family were designed from published database sequences to be homologous for both rat and mouse. Quantitative PCR (qPCR) was performed in a $20 \mu \mathrm{l}$ reaction mix using platinum SYBR Green qPCR Supermix UDG (Invitrogen), in triplicate, as per the manufacturer's instructions. The PCR program was $50^{\circ} \mathrm{C}$ for $2 \mathrm{~min}$ and $94^{\circ} \mathrm{C}$ for $2 \mathrm{~min}$, followed by 40 cycles of $94^{\circ} \mathrm{C}$ for $30 \mathrm{~s}, 58^{\circ} \mathrm{C}$ for $30 \mathrm{~s}$, and $72^{\circ} \mathrm{C}$ for $30 \mathrm{~s}$. To ensure that amplified products were the correct size and reflected the data generated by the Rotor Gene 3000 Q-PCR machine (Corbett Research, Sydney, Australia), products were run on a $2 \%$ agarose gel (Qiagen, Melbourne, Australia) containing ethidium bromide. All gene amplification was standardized to $18 \mathrm{~S}$ controls, and "no-reverse transcriptase reaction" controls were also examined for $18 \mathrm{~S}$ mRNA expression. Gene expression was quantified as fold differences. PC12 cell cDNA was used as a positive control for both $\mathrm{p} 75^{\mathrm{NTR}}$ and tropomyosinrelated kinase A (trkA) primers, whereas P2 rat brainstem cDNA was used to ensure correct amplification of trkB and trkC products.

\section{Results}

p75 ${ }^{\text {NTR }}$ expression identifies a restricted population of cells in the SVZ of neonatal and adult rats

After the detection of $\mathrm{p} 75^{\mathrm{NTR}}$ mRNA expression in a purified adult mouse SVZ stem cell population (Rietze et al., 2001) by gene microarray and reverse transcription-PCR (supplemental Fig. 1, available at www.jneurosci.org as supplemental material), we examined p $75^{\text {NTR }}$ expression in the SVZ of adult and early postnatal (P2) rats by immunostaining coronal brain sections using anti-p $75^{\text {NTR }}$ antibodies.

In the adult rat forebrain, $\mathrm{p} 75^{\mathrm{NTR}}$ expression was restricted to the basal forebrain (data not shown) and the lateral wall and dorsolateral corner of the SVZ (Fig. 1a). At P2, in addition to the p $75^{\text {NTR }}$ immunostaining observed in the cortical subplate, a discrete population of $\mathrm{p} 75^{\mathrm{NTR}}$-positive cells was present within the SVZ. The expression pattern was similar to that observed in the adult, with p $75^{\mathrm{NTR}}$-positive cells again observed primarily in the dorsolateral corner of the SVZ (Fig. 1b,c). All cells that were immunopositive for the expression of extracellular p $75^{\text {NTR }}$ (Fig. $1 b$ ) coexpressed the intracellular domain of $\mathrm{p} 75^{\text {NTR }}$ (Fig. 1c). Without permeabilization, clearly punctate cell-surface receptor staining could be observed on a small proportion of SVZ cells after dissociation (Fig. 2c). To further immunocharacterize the p $75^{\text {NTR }}$-positive cells, sections of adult SVZ were costained for a variety of antigens associated with known SVZ cell types. The majority of the $\mathrm{p} 75^{\mathrm{NTR}}$-positive cells did not express detectable levels of GFAP (astrocytes) (Fig. 1a,d), S100 $\beta$ (neuroglia) (Fig. 1e), Sox10 (oligodendrocyte lineage) (Fig. $1 f$ ), doublecortin (immature neuroblasts) (Fig. 1g), PSA-NCAM (neuroblasts) (Fig. $1 h$ ), or NeuN (neurons) (Fig. 1i), but did comprise a discrete nestin-positive (neural precursor) (Fig. 1j) population, amid the other cell populations. Although cells expressing a high level of p $75^{\mathrm{NTR}}$ never coexpressed the immature neuroblast marker doublecortin (Fig. 1h), there were occasional cells expressing a low level of $\mathrm{p} 75^{\mathrm{NTR}}$ protein that coexpressed a low level of doublecortin or PSA-NCAM (Fig. $1 h$, inset), whereas others occasionally coexpressed GFAP (Fig. 1e). All p75 ${ }^{\mathrm{NTR}}$-positive cells occurred in subependymal clusters, and a few contained processes that could be seen extending to contact the ventricle (Fig. $1 a$, inset). At both ages examined, we estimated that $\mathrm{p} 75^{\mathrm{NTR}}$-positive cells accounted for $<1 \%$ of the total number of cells in the SVZ. These coexpression studies indicate that $\mathrm{p} 75^{\mathrm{NTR}}$ is expressed by SVZ precursor cells.

To quantify the number of $\mathrm{p} 75^{\mathrm{NTR}}$-positive cells more accurately, freshly dissociated SVZ was immunostained with a monoclonal anti-extracellular p $75^{\text {NTR }}$ antibody and assessed by flow cytometry. Three populations of cells were sorted based on their fluorescence intensity: p75 ${ }^{\mathrm{NTR}}$-high, p $75^{\mathrm{NTR}}$-mid, and p $75^{\mathrm{NTR}}$ negative (Fig. 2a,b). Consistent with the small proportion of p $75^{\text {NTR }}$-immunopositive cells detected in sections, $\sim 0.3 \%$ of adult $(0.33 \pm 0.2 \%$; mean $\pm \mathrm{SD} ; n=3$ experiments $)$ and $\mathrm{P} 2$ $(0.29 \pm 0.05 \%$; mean $\pm \mathrm{SD} ; n=6$ experiments) SVZ cells were deemed $\mathrm{p} 75^{\mathrm{NTR}}$ positive by flow cytometry. The $\mathrm{p} 75^{\mathrm{NTR}}$-high cells (Fig. $2 c, d$ ) had an endogenous level of p $75^{\mathrm{NTR}}$ expression equivalent to that of PC12 cells (Barrett and Georgiou, 1996), whereas the $\mathrm{p} 75^{\mathrm{NTR}}$-negative cells (Fig. $2 e, f$ ) displayed negligible fluorescence, equivalent to that of unstained cells.

After separating the $\mathrm{p} 75^{\mathrm{NTR}}$-high, -mid, and -negative cells from the P2 rat SVZ, the level of p75 ${ }^{\text {NTR }}$ mRNA expression was assessed by quantitative PCR and was found to directly mirror p75 ${ }^{\text {NTR }}$ protein levels: p75 ${ }^{\text {NTR }}$ mRNA was most strongly expressed in the $\mathrm{p} 75^{\mathrm{NTR}}$-high cell population, with fourfold less mRNA present in $\mathrm{p} 75^{\mathrm{NTR}}$-mid cells and negligible expression levels in p $75^{\mathrm{NTR}}$-negative cells (Fig. $2 g$ ).

\section{p75 ${ }^{\text {NTR }}$-expressing cells exhibit stem cell characteristics}

To phenotypically characterize the $\mathrm{p} 75^{\mathrm{NTR}}$-positive SVZ cells, purified $\mathrm{p} 75^{\mathrm{NTR}}$-high, -mid, and -negative cells from the adult and postnatal SVZ were cultured clonally in neurospheregenerating conditions to examine their proliferative potential. Remarkably, in the adult SVZ, all of the neurosphere-forming cells were $\mathrm{p} 75^{\mathrm{NTR}}$ positive, with $81.4 \pm 16.5 \%$ of the p $75^{\mathrm{NTR}}{ }_{-}$ positive cells generating neurospheres by day 7 in vitro (mean \pm SD; $n=3$ experiments; $t_{0}=24 \mathrm{~h}$ ). Although $61.82 \pm 15.5 \%$ of the p $75^{\text {NTR }}$-negative cells survived the week in culture, and many had the morphology of differentiated cell types, all failed to generate neurospheres (mean $\pm \mathrm{SD} ; n=3$ experiments).

The highest frequency of neurosphere formation from the P2 SVZ was also found in the $\mathrm{p} 75^{\mathrm{NTR}}$-high population. When cells were seeded at a density of one cell per well into 96-well plates, approximately one-half of the $\mathrm{p} 75^{\mathrm{NTR}}$-high cells proliferated to form neurospheres (Fig. $3 a$ ). An additional 10.33 $\pm 6.02 \%$ survived the week in culture, although $42.88 \pm 6.88 \%$ (mean \pm SD; $n=2$ experiments) of plated cells died within the first $30 \mathrm{~h}$ of sorting and plating. Therefore, $>80 \%$ of $\mathrm{p} 75^{\mathrm{NTR}}$-high cells surviving their first day in culture proliferated to generate a neurosphere. In contrast, $<10 \%$ of the p $75^{\mathrm{NTR}}$-negative cells formed neurospheres under equivalent culture conditions (Fig. $3 a$ ).

These data indicate that, unlike in the adult, in which all proliferating cells express $\mathrm{p} 75^{\mathrm{NTR}}$, the postnatal SVZ contains two distinct proliferative populations. Despite the cells being phenotypically different with respect to their cell-surface p $75^{\text {NTR }}$ expression, clonally plated cells that were able to proliferate from the $\mathrm{p} 75^{\mathrm{NTR}}$-high, -mid, and -negative populations did so to the same extent, generating neurospheres that were of an equivalent average size (Table 1) and that appeared morphologically similar (bulk culture examples) (Fig. 3b,c). Furthermore, bulk and 


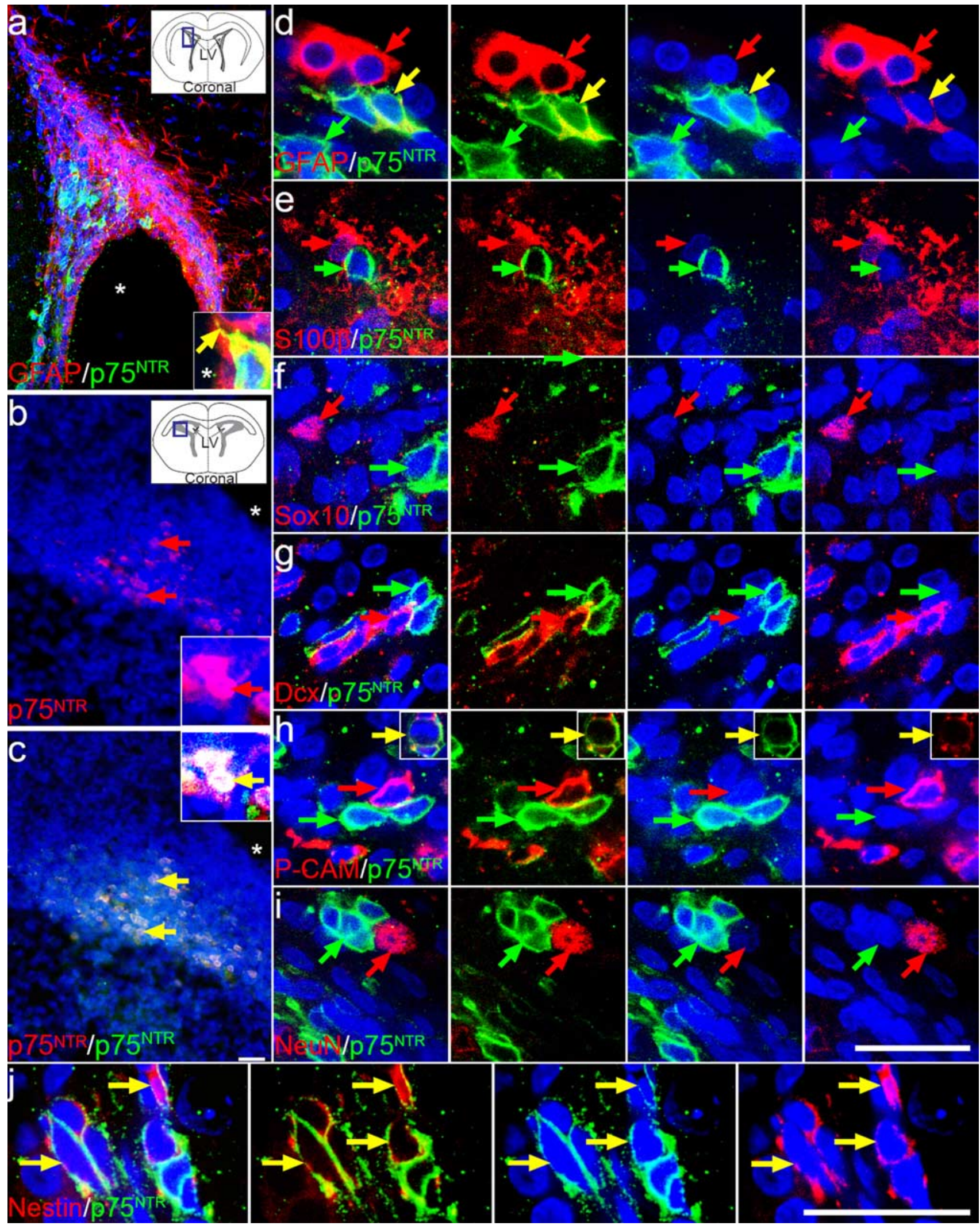

Figure 1. A restricted population of cells in the SVZ express $\mathrm{p} 75^{\mathrm{NTR}} \cdot \boldsymbol{a}$, Compressed confocal stack showing a coronal section of an adult rat brain stained with anti-intracellular p $75^{\mathrm{NTR}}$ (Promega; green) and anti-GFAP-CY3 (Sigma; red). A higher-magnification single confocal scan is inset and depicts a single colabeled cell with a process that extends to contact the ventricle. The photographed region is illustrated in the inset schematic of the coronal brain section. $\boldsymbol{b}, \boldsymbol{c}$, The dorsolateral corner of the SVZ of early postnatal (P2) rat brain also contained p75 ${ }^{\text {NTR }}$-immunoreactive cells [same section stained with both MC192 ( $\boldsymbol{b}$, red) and anti-intracellular p75 ${ }^{\mathrm{NTR}}\left(\boldsymbol{c}\right.$, green)]. A higher-magnification image of the colabeled cells is inset. p75 ${ }^{\mathrm{NTR}}$-positive cells (Promega; green) in the adult rat SVZ were examined for colocalization with GFAP (d, red), S100 $\beta(\boldsymbol{e}$, red), Sox10 (f, red), doublecortin (Dcx; $\boldsymbol{g}$, red), PSA-NCAM (P-CAM; $\boldsymbol{h}$, red), NeuN (i, red), and nestin (j, red) in $30 \mu \mathrm{m}$ sections, analyzed by confocal microscopy (single confocal scans shown). Sections were counterstained with the nuclear dye DAPI (blue), and the lateral ventricle (LV) is indicated by asterisks. Yellow arrows indicate colocalization events for the sets of markers illustrated. Scale bars, $50 \mu \mathrm{m}$. 

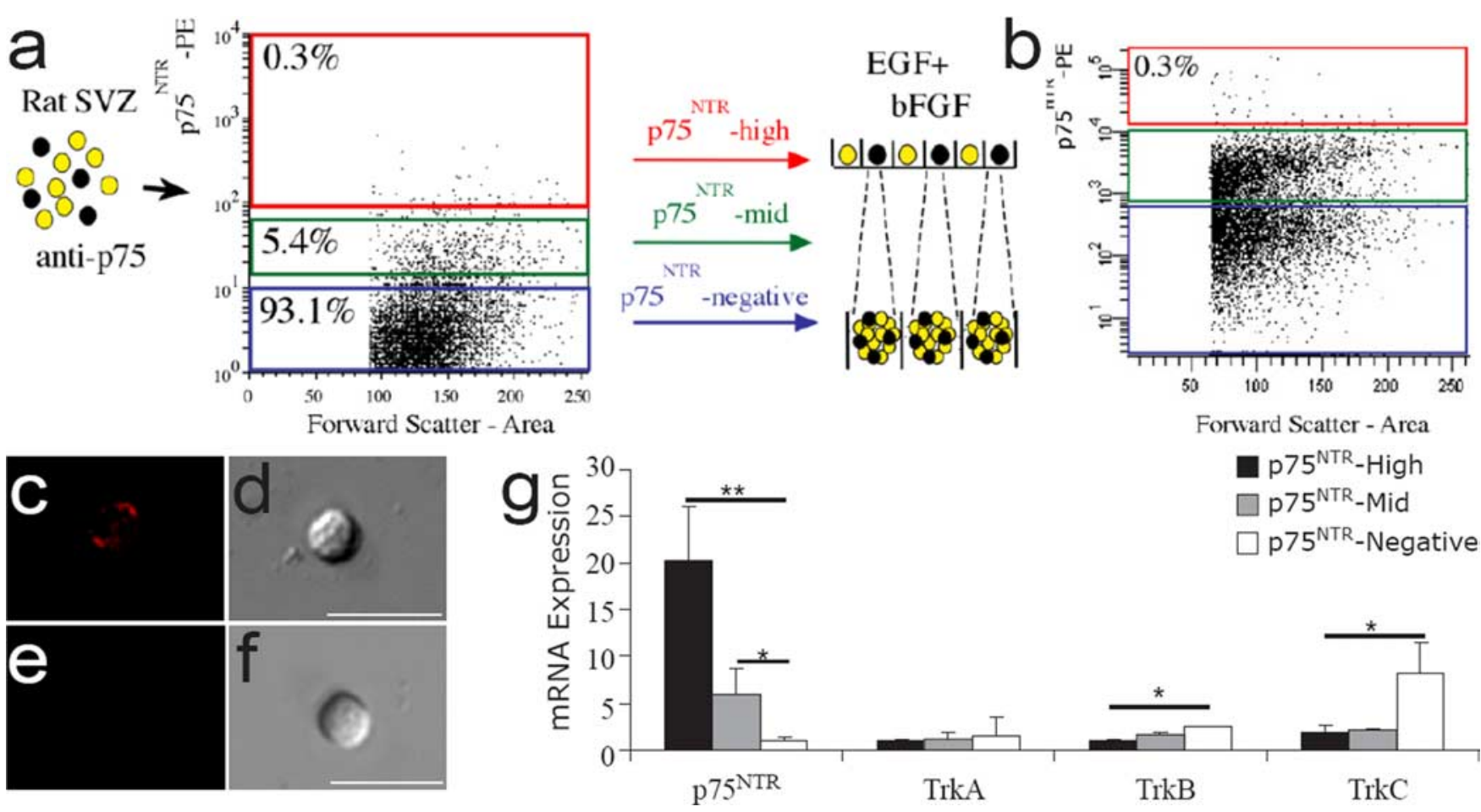

Figure 2. Purification of p75 NTR -positive cells from rat SVZ. $\boldsymbol{a}, \boldsymbol{b}$, Freshly isolated and dissociated P2 (a) and adult (b) rat SVZ cells were immunostained with the mouse anti-rat extracellular p75 ${ }^{\text {NTR }}$ antibody (Millipore) and sorted by flow cytometry into three populations, as shown in the representative profiles. p75 ${ }^{\text {NTR }}$-high, -mid, and -negative cell regions are indicated by the red, green, and blue boxes, respectively. Collected cells were either plated into neurosphere-generating conditions, usually at a clonal density, or snap frozen for RNA analysis. $\boldsymbol{c}, \boldsymbol{d}$, Approximately $0.3 \%$ of SVZ cells were of equivalent intensity to PC12 cells (positive control) and were considered highly immunopositive (fluorescence, $\boldsymbol{c}$; phase, $\boldsymbol{d}$ ). Five percent of cells were in the p75 ${ }^{\text {NTR }}$-mid population and were of equivalent intensity to cells incubated with secondary antibody alone. $\boldsymbol{e}, \boldsymbol{f}$, The majority of cells (93\%) were immunonegative for p $75^{\mathrm{NTR}}$ expression (fluorescence, $\boldsymbol{e} ;$; phase, f). $g$, Neurotrophin receptor mRNA expression by quantitative PCR for each sorted population, standardized to 185 amplification, and expressed as relative fold differences. p75 ${ }^{\text {NTR }} \mathrm{mRNA}$ was most highly expressed in the sorted $p 75^{\text {NTR }}$-high cells, with p $75^{\text {NTR }}$ mRNA also detected in the p75 ${ }^{\text {NTR }}$-mid cells. Sorted p75 $5^{\text {NTR }}$-negative cells did not contain detectable levels of p75 ${ }^{\text {NTR }}$ mRNA. Primers for trkA, trkB, or trkC mRNA failed to amplify mRNA from $p 75^{\text {NTR }}$-high cells. There was a small but significant amplification of trkB mRNA and robust full-length (shown) and truncated trkC $m$ RNA amplification from sorted $p 75^{\text {NTR }}$-negative cells. ${ }^{*} p<0.05 ;{ }^{* *} p<0.01$; mean \pm SD; $n=3$ experiments.

clonally derived neurospheres grown from $\mathrm{p} 75^{\mathrm{NTR}}$-high and p $75^{\mathrm{NTR}}$-negative cells could be passaged, with an equivalent proportion of cells consistently generating secondary neurospheres (p75 ${ }^{\mathrm{NTR}}$-high, $14.7 \pm 4.6 \%$; p $75^{\mathrm{NTR}}$ negative, $17.3 \pm 4.6 \%$; mean $\pm \mathrm{SD} ; n=3$ experiments; $p>0.05)$. Serial passaging of these cultures ( $>3$ times) indicated that cells within both populations could self-renew. Thus, in terms of proliferation and selfrenewal, there were no obvious differences between the neurospheres derived from p $75^{\mathrm{NTR}}$-high and p $75^{\mathrm{NTR}}$-negative cells, suggesting that $\mathrm{p} 75^{\mathrm{NTR}}$ signaling was not influencing these two characteristic stem cell processes.

\section{Neurotrophins promote neurogenesis exclusively in the p75 ${ }^{\mathrm{NTR}}$-positive cell population}

Because BDNF signaling has been repeatedly linked with neurogenesis, we investigated the possibility that neurotrophin treatment of the p $75^{\mathrm{NTR}}$-positive cells would stimulate the generation of neurogenic progeny. To assess the effects of BDNF and p75 NTR on neurogenesis, p75 ${ }^{\mathrm{NTR}}$-high, -mid, and -negative cells were sorted from the P2 SVZ and again cultured, this time in the presence or absence of exogenous BDNF. BDNF was found to have no effect on the frequency of primary neurosphere production, neurosphere size (Table 1), or secondary neurosphere generation ( $\mathrm{p} 75^{\mathrm{NTR}}$-high, $14.7 \pm 4.6 \%$; $75^{\mathrm{NTR}}$-high plus BDNF, $15.4 \pm 3.7 \%$; mean \pm SD; $n=3$ experiments; $p>0.05)$. Primary neurospheres were also transferred into differentiating conditions lacking mitogens or exogenous neurotrophins for an additional $2 \mathrm{~d}$ to allow neuron detection by $\beta$-III-tubulin immuno- cytochemistry. In the differentiated cultures, we observed that, even when grown in the absence of BDNF, $>60 \%$ of the neurospheres derived from $\mathrm{p} 75^{\mathrm{NTR}}$-positive cells contained $\beta$-IIItubulin-expressing neurons, compared with $<20 \%$ of those generated from the p $75^{\mathrm{NTR}}$-negative cells (Fig. $4 a$ ). The addition of BDNF enhanced this effect, increasing the number of neurons generated by each p $75^{\text {NTR }}$-high cell in a dose-dependent manner (Fig. $4 b-e$ ). However, even at the highest concentration tested $(100 \mathrm{ng} / \mathrm{ml}), \mathrm{BDNF}$ had no effect on the $\mathrm{p} 75^{\mathrm{NTR}}$-negative population, resulting in $<2 \%$ of the number of neurons produced by p75 ${ }^{\text {NTR }}$-high cells (Fig. $4 b$ ). Cells within the p $75^{\text {NTR }}$-mid population were able to respond to BDNF treatment, but the magnitude of the response was well below that observed in the p $75^{\text {NTR }}$ high population.

The majority of neurospheres generated from $\mathrm{p} 75^{\mathrm{NTR}}$-high (Fig. $4 c$ ) cells and some of the p75 ${ }^{\mathrm{NTR}}$-negative neurospheres (Fig. $4 d$ ) contained GFAP-positive astrocytes, O4-positive oligodendrocytes, and $\beta$-III-tubulin-positive neurons, indicative of the third stem cell characteristic of multipotentiality. However, under basal conditions, the vast majority of $\mathrm{p} 75^{\mathrm{NTR}}$-negative neurospheres $(\sim 80 \%)$ consisted primarily of GFAP-positive cells. The addition of BDNF to $\mathrm{p} 75^{\mathrm{NTR}}$-positive cells increased the incidence of neurospheres containing $\beta$-III-tubulin-positive neurons (Fig. $4 a$ ), to the extent that all of the neurospheres derived from p $75^{\mathrm{NTR}}$-high cells contained neurons. Furthermore, the number of neurons within individual neurospheres derived from $\mathrm{p} 75^{\mathrm{NTR}}$-positive cells also significantly increased (Fig. $4 b$ ). However, the number of astrocytes or oligodendrocytes per 

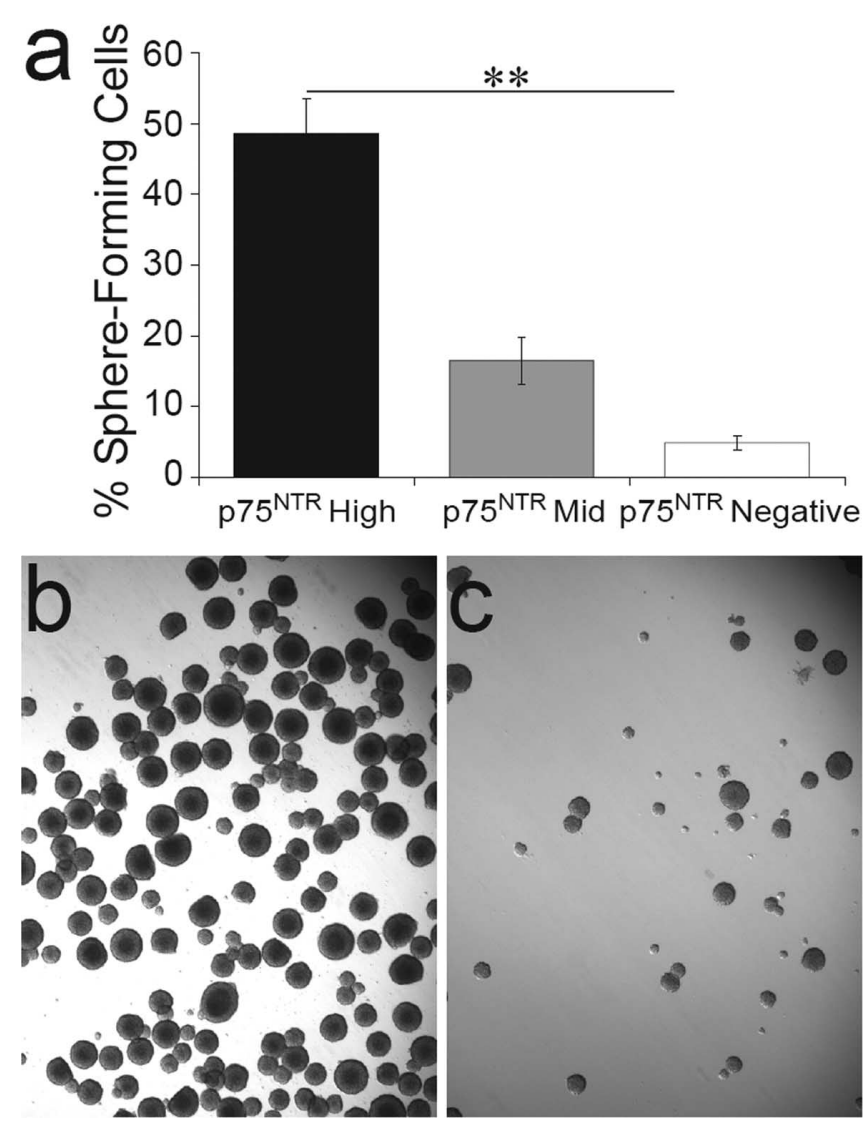

Figure 3. SVZ p $75^{\text {NTR }}$-positive cells generate neurospheres. $\boldsymbol{a}$, Freshly isolated and dissociated P2 rat SVZ cells were sorted by flow cytometry based on their level of $p 75^{\mathrm{NTR}}$ expression. Collected cells were subsequently cultured at a density of one cell per well in mitogenic medium (clonal density confirmed by light microscopy $4 \mathrm{~h}$ after plating). Neurosphere formation was assessed after 1 week and expressed as a percentage of the number of cells counted at $4 \mathrm{~h}$ after plating. $75^{\mathrm{NTR}}$ expression enriched for cells that generated neurospheres $\left({ }^{* *} p<0.0001\right)$. The majority of $\mathrm{p} 75^{\mathrm{NTR}}$-high cells that did not form neurospheres underwent cell death, when all cells were accounted for $7 \mathrm{~d}$ after plating (mean $\pm S D ; n=5$ experiments). $\boldsymbol{b}, \boldsymbol{c}$, Photomicrographs of high-density cultures seeded from an equivalent numbers of P2 SVZ p75 ${ }^{\text {NTR }}$-high (b) or $\mathrm{p} 75^{\mathrm{NTR}}$-negative (c) cells clearly demonstrate the difference in frequency of neurosphere formation between these two populations but the similarity of morphology of the resulting neurospheres in each culture.

neurosphere did not change, suggesting that the increased neurogenesis was not a result of lineage switching.

It appeared that BDNF was acting directly on the proliferating p $75^{\mathrm{NTR}}$-positive cells, because, to promote neurogenesis, it had to be added to the primary sorted cells. The addition of BDNF to mature p $75^{\mathrm{NTR}}$-high, -mid, and -negative neurospheres solely during their $2 \mathrm{~d}$ differentiation period increased neurite outgrowth in all neurospheres, regardless of $\mathrm{p} 75^{\mathrm{NTR}}$ expression, without influencing neuron number (data not shown). Consistent with this finding, we found $\mathrm{p} 75^{\mathrm{NTR}}$ expression to be significantly downregulated under culture conditions (supplemental Fig. 2, available at www.jneurosci.org as supplemental material). Therefore, BDNF appears to regulate neuron number by acting on $\mathrm{p} 75^{\mathrm{NTR}}$-positive precursors during the proliferative phase of neurosphere growth, but it may also affect the phenotype of newly born neurons by other p $75^{\mathrm{NTR}}$-independent pathways.

To determine whether BDNF was signaling either through p $75^{\text {NTR }}$ alone or in conjunction with trkB, the expression of other neurotrophin receptors was assessed for each sorted population. Trk receptor mRNAs (including both catalytic and noncatalytic forms of trkB and trkC) were not amplified from cDNA gener- ated from the $\mathrm{p} 75^{\mathrm{NTR}}$-high or p $75^{\mathrm{NTR}}$-mid cells (Fig. $1 g$ ), despite amplification from PC12 cells (trkA) and brainstem (trkB and trkC) (data not shown). However, a small but significant amount of trkB and both forms of trkC receptor mRNA were amplified from the $\mathrm{p} 75^{\mathrm{NTR}}$-negative population (Fig. $1 \mathrm{~g}$ ). These data suggested that BDNF was unlikely to be promoting neuron generation by $\mathrm{p} 75^{\mathrm{NTR}}$-positive cells through a p $75^{\mathrm{NTR}} / \mathrm{trkB}$ heterodimer.

Although high levels of trk receptor mRNA were not detected in freshly sorted $\mathrm{p} 75^{\mathrm{NTR}}$-high cells, trkB and trkC but not trkA mRNA was detected in cultured neurospheres (data not shown). Therefore, it was possible that BDNF could have driven neurogenesis in vitro by affecting trkB-expressing cells generated after the initial cell division. Because trkA was never present, we treated purified p $75^{\mathrm{NTR}}$-high cells with $100 \mathrm{ng} / \mathrm{ml}$ nerve growth factor (NGF) to determine whether this could also stimulate p $75^{\mathrm{NTR}}$-mediated neurogenesis independent of trk signaling. Although not as potent as BDNF, NGF was able to stimulate neurogenesis, causing a $2.02 \pm 0.12$-fold increase in the number of neurons generated by each neurosphere (mean $\pm \mathrm{SD}$; $n=3$ experiments). Because BDNF and NGF are both able to promote neurogenesis, and $\mathrm{p} 75^{\mathrm{NTR}}$ is the common receptor for both neurotrophins, it seemed most likely that $\mathrm{p} 75^{\mathrm{NTR}}$ alone was necessary to signal neuronal commitment in the purified cells.

\section{p $75^{\text {NTR }}$ signaling promotes neuroblast formation in the adult SVZ}

Although our previous data provided strong support for BDNF signaling through $\mathrm{p} 75^{\mathrm{NTR}}$ being sufficient to promote neurogenesis without trk receptor coactivation, we investigated this further by analyzing $\mathrm{BDNF}$ responsiveness and neurogenesis in p $75^{\mathrm{NTR}+1+}$ and $\mathrm{p} 75^{\mathrm{NTR}-1-}$ mice.

First, neurospheres were generated from newborn $\mathrm{p} 75^{\mathrm{NTR}-/-}$ mice. These were then differentiated, revealing that both p $75^{\mathrm{NTR}+/+}$ (Fig. 5a) and p75 ${ }^{\mathrm{NTR}-/-}$ (Fig. 5b) neurosphere cultures contained neurons, oligodendrocytes, and astrocytes and a similar total number of cells per size-matched neurosphere (DAPI-positive cells for p $75^{\mathrm{NTR}+/+}, 408.75 \pm 46.25$; $775^{\mathrm{NTR}-/-}$, $426.25 \pm 88.75 ; p>0.05)$. Strikingly, neurospheres generated from $\mathrm{P} 2 \mathrm{p} 75^{\mathrm{NTR}-1-}$ mice contained $75 \%$ fewer neurons than neurospheres generated from $\mathrm{p} 75^{\mathrm{NTR}+1+}$ littermates $\left(\mathrm{p} 75^{\mathrm{NTR}+/+}, 5.3 \pm 0.9 \% ; \mathrm{p}^{\mathrm{NTR}-/-}, 1.3 \pm 0.3 \% ; p<0.01\right.$; mean $\pm \mathrm{SD} ; n=3$ experiments). A similar distinction was observed between $\mathrm{p} 75^{\mathrm{NTR}+/+}$ and $\mathrm{p} 75^{\mathrm{NTR}-/-}$ adult cultures (data not shown). Quantification of the number of oligodendrocytes and astrocytes showed no significant change in either population.

To determine whether BDNF was acting directly via p $75^{\text {NTR }}$ to promote neurogenesis, dissociated adult $\mathrm{p} 75^{\mathrm{NTR}-1-}$ and p $75^{\text {NTR }+/+}$ SVZ cells were treated with the neurotrophin, and the number of neurons within the resulting neurospheres was determined after differentiation. Treatment with $30 \mathrm{ng} / \mathrm{ml}$ BDNF resulted in an $80 \%$ increase $(p<0.01)$ in the number of $\beta$-IIItubulin-positive neurons contained within $\mathrm{p} 75^{\mathrm{NTR}+/+}$ neurospheres compared with untreated $\mathrm{p} 75^{\mathrm{NTR}+/+}$ neurospheres. No significant change in neuronal number was seen in size-matched p75 $5^{\mathrm{NTR}-1-}$ neurospheres with or without BDNF treatment, further indicating that $\mathrm{p} 75^{\mathrm{NTR}}$ is both necessary and sufficient to transduce the proneurogenic signal of BDNF.

That $\mathrm{p} 75^{\mathrm{NTR}}$ signaling was shown to have such a significant effect on neurogenesis in vitro suggested that the absence of p $75^{\text {NTR }}$ would disrupt neurotrophin-regulated neurogenesis in vivo. We therefore examined the effect of p $75^{\mathrm{NTR}}$ deficiency on neuroblast production. The level of PSA-NCAM immunoreac- 
tivity within the SVZ was used as a reflection of neuroblast numbers to allow comparisons to be drawn between adult p $75^{\mathrm{NTR}+/+}$ and $75^{\mathrm{NTR}-/-}$ mice. p $75^{\mathrm{NTR}-1-}$ animals had a $25 \%$ reduction in the pixel density of PSA-NCAM labeling along the extent of the lateral wall of the lateral ventricle when compared with p $75^{\mathrm{NTR}+/+}$ mice $\left(\mathrm{p} 75^{\mathrm{NTR}+/+}, 78,080 \pm\right.$ 3842; p75 ${ }^{\mathrm{NTR}-1-}, 58,850 \pm 4625 ;$ mean \pm $\mathrm{SD} ; n=6 ; p<0.05$ ) (Fig. $5 c, d$ ). Furthermore, when examined by flow cytometry, the number of PSA-NCAM-positive cells in the dorsolateral corner of the lateral ventricle of adult $\mathrm{p} 75^{\mathrm{NTR}-1-}$ mice was $55.85 \pm 10.42 \%$ (mean \pm SEM; $n=4$ experiments; $p<0.01$ ) of that found in p $75^{\mathrm{NTR}+/+}$ mice. This suggests that p $75^{\text {NTR }}$ signaling may be responsible for half of the neurogenesis that occurs under normal physiological circumstances.

Because the SVZ, via the rostral migratory stream, provides new neurons to the adult olfactory bulb, a reduction in adult SVZ neurogenesis should result in a reduction in the growth of the olfactory bulb. The olfactory bulbs of $\mathrm{p} 75^{\mathrm{NTR}-1-}$ mice were smaller than those of wild-type mice and weighed 15-30\% less than those of $\mathrm{p} 75^{\mathrm{NTR}+/+}$ controls at all ages examined (P2, 7 weeks, and 10 months of age) (Fig. 5e), even when corrected for differences in brain weight. These data support a physiological function for $\mathrm{p} 75^{\mathrm{NTR}}$ in the ongoing generation of SVZ neuroblasts destined for the olfactory bulb.

\section{Discussion}

Our results demonstrate that $\mathrm{p} 75^{\mathrm{NTR}}$ expression defines a population of stem or precursor cells in the SVZ that persists from development to adulthood and is able to respond to neurotrophin stimulation and promote the generation of daughter neuroblasts and neurons both in vitro and in vivo.

Approximately $0.3 \%$ of cells in the rat SVZ express p $75^{\text {NTR }}$ throughout postnatal life, a proportion that corresponds to the number of neurosphere-forming (both stem and progenitor) cells reported to exist in the adult SVZ (Weiss et al., 1996; Rietze et al., 2001). We found that the majority of p $75^{\mathrm{NTR}}$-expressing cells purified from the SVZ of both newborn and adult rats were capable of forming a neurosphere, and many $\mathrm{p} 75^{\mathrm{NTR}}$-positive cells also exhibited the other stem cell characteristics of selfrenewal and multipotentiality (Reynolds and Weiss, 1992; Reynolds et al., 1992; Richards et al., 1992; Doetsch et al., 1999, 2002; Rietze et al., 2001). However, because p $75^{\mathrm{NTR}}$-positive cells accounted for all of the neurosphere-forming cells in the adult SVZ, this population probably contains both stem and progenitor cells.

Histological analyses revealed that the majority of $\mathrm{p} 75^{\mathrm{NTR}}$ positive cells were spherical subependymal cells that were found in close proximity to neuroblasts. These cells expressed nestin but not detectable levels of mature neural or neuroblast markers (Rousselot et al., 1995), a phenotype consistent with that reported for type C precursor cells (Doetsch et al., 1997, 2002).
However, we also detected occasional p $75^{\text {NTR }}$-high cells that coexpressed GFAP, some of which extended processes to make contact with the ventricle, a characteristic associated with the subpopulation of GFAP-positive B cells that are reported to be the SVZ neural stem cells (Doetsch et al., 1997, 1999). These coexpression studies are consistent with our in vitro functional assessment of the $\mathrm{p} 75^{\mathrm{NTR}}$-expressing population and indicate that $\mathrm{p} 75^{\mathrm{NTR}}$ is a specific selection marker for neural stem cells and uncommitted multipotent SVZ progenitors (collectively discussed hereafter as precursor cells).

Using $\mathrm{p} 75^{\mathrm{NTR}}$ as a marker, we identified an important difference between precursor activity in the neonate and that in the adult. Although the p75 ${ }^{\text {NTR }}$ precursors present at both ages occurred with the same frequency and had the same phenotypic properties, the neonate contained a second $\mathrm{p} 75^{\mathrm{NTR}}$-negative population. Most of the neurospheres generated by $\mathrm{p} 75^{\mathrm{NTR}}$ negative cells contained only glia, suggesting that the p75 ${ }^{\mathrm{NTR}}$ negative precursors were highly proliferative but with a reduced lineage potential. These cells may represent a more restricted progenitor population related to the astrocytic production that occurs at this developmental stage (Altman, 1966; Levers et al., 2001). These astrocytic precursors contribute to the high frequency of proliferative cells present in the P2 SVZ but do not persist into adulthood, indicating that $\mathrm{p} 75^{\mathrm{NTR}}$ may be useful as a specific postnatal marker of those neurogenic precursor cells that persist into adulthood.

Because $\mathrm{p} 75^{\mathrm{NTR}}$ signaling is primarily known to regulate cell death and survival decisions, we investigated the possibility that p $75^{\text {NTR }}$ was promoting neurogenesis by mediating SVZ cell sur- 

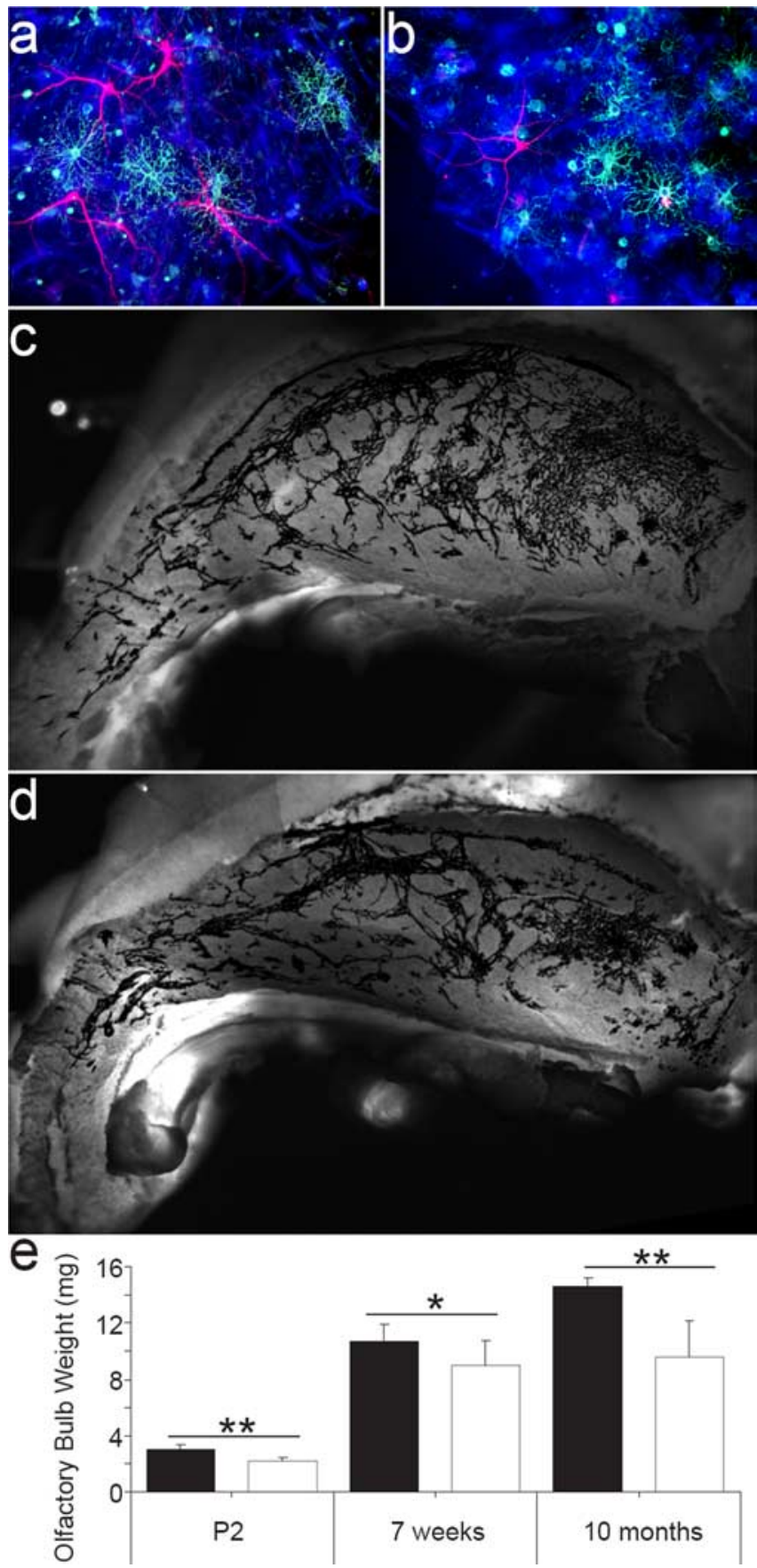

Figure 5. $p 75^{\mathrm{NTR}}$ activation promotes neurogenesis in vitro and in vivo. $\boldsymbol{a}, \boldsymbol{b}$, Differentiated neurospheres derived from both $\mathrm{p} 75^{\mathrm{NTR}+/+}(\boldsymbol{a})$ and $\mathrm{p} 75^{\mathrm{NTR}-/-}(\boldsymbol{b})$ clonal cultures contain $\beta$-III-tubulin-positive neurons (red), 04-positive oligodendrocytes (green), and GFAP-positive astrocytes (blue). $\boldsymbol{c}, \boldsymbol{d}$, Photomicrographs of whole-mount preparations from adult $\mathrm{p} 75^{\mathrm{NTR}+1+}$ (c) and p75 ${ }^{\mathrm{NTR}-1-}$ (d) mice depict PSA-NCAM staining (black) in the lateral wall of the lateral ventricle. $\boldsymbol{e}$, The weight $(\mathrm{mg}$ ) of individual olfactory bulbs from P2, 7 week, and 10-month-old $\mathrm{p} 75^{\mathrm{NTR}+/+}$ and $\mathrm{p} 75^{\mathrm{NTR}-1-}$ mice was determined. At all ages, the olfactory bulbs of p75 ${ }^{\mathrm{NTR}-1-}$ mice weighed less than those of wild-type animals. ${ }^{*} p<0.05$; ${ }^{* *} p<0.001$; mean $\pm S D ; n=7,5$, and 8 animals, respectively, per genotype.

vival. However, the frequency of primary neurospheres generated from the SVZ of adult $\mathrm{p} 75^{\mathrm{NTR}+1+}$ and $\mathrm{p} 75^{\mathrm{NTR}-1-}$ mice was found to be equivalent, as was the number of neurospheres generated under basal and neurotrophin-treated (p75 NTR stimulated) conditions, indicating that $\mathrm{p} 75^{\mathrm{NTR}}$ was not necessary for precursor survival in vivo. Furthermore, the size of the neu- rospheres produced from $\mathrm{p} 75^{\mathrm{NTR}+/+}$ versus $\mathrm{p} 75^{\mathrm{NTR}-/-}$ mice or under basal versus neurotrophin-treated conditions did not differ for any population analyzed, suggesting that $\mathrm{p} 75^{\mathrm{NTR}}$ was not promoting the death or survival of neurosphere progeny in vitro. Thus, the mechanism by which $\mathrm{p} 75^{\mathrm{NTR}}$ promotes neurogenesis is unlikely to involve regulating precursor or progenitor survival. Nevertheless, high levels of p75 ${ }^{\mathrm{NTR}}$ expression in neuroblasts have been associated with increased cell death when the neuroblasts are prevented from migrating (Gascon et al., 2007), although such cell death has not been shown to be caused by $\mathrm{p} 75^{\mathrm{NTR}}$ signaling per se. We propose that activation of $\mathrm{p} 75^{\mathrm{NTR}}$ on SVZ precursors favors neuroblast generation, a function consistent with the ability of $\mathrm{p} 75^{\mathrm{NTR}}$ to promote cell cycle progression and terminal differentiation in other systems (Cattaneo and McKay, 1990; Seidl et al., 1998; Lachyankar et al., 2003). For example, neurotrophin-stimulated signaling has been shown to act through downstream $\mathrm{p} 75^{\mathrm{NTR}}$-interacting proteins, such as Schwann cell factor-1, to promote withdrawal from the cell cycle (Chittka and Chao, 1999; Chittka et al., 2004) and facilitate the expression of differentiation-promoting genes (Ito et al., 2003).

In postnatal and adult animals, basal and neurotrophinstimulated SVZ neuron production was dependent on $\mathrm{p} 75^{\mathrm{NTR}}$ expression and signaling. However, purified $\mathrm{p} 75^{\mathrm{NTR}}$-positive precursors represent not only a highly proliferative but also a highly neurogenic population. Conversely, SVZ precursors from mice deficient in p $75^{\text {NTR }}$ generate dramatically fewer neurons than wild-type precursors in vitro. Moreover, we found that BDNF was capable of stimulating $\mathrm{p} 75^{\mathrm{NTR}}$-positive precursor cells, strongly promoting neurogenesis. A single dose of BDNF at the time of cell plating was sufficient to drive neuronal production within neurospheres, whereas the application of BDNF to mature neurospheres was ineffective, suggesting a direct action of BDNF through p $75^{\text {NTR }}$ expressed by SVZ precursors, to influence the outcome of cell division. BDNF has previously been shown to promote neuroblast survival and maturation through trkB expressed by these cells (Benraiss et al., 2001), which explains our observation that BDNF altered neuronal morphology if applied to differentiating neurospheres. However, with regards to the precursor population, our results indicate that a trk coreceptor is not present. NGF stimulated neurogenesis, despite the complete absence of trkA mRNA in cells from the SVZ, purified p75 ${ }^{\text {NTR }}$-positive cells, and cultured neurospheres. In addition, trkB was not detected in p $75^{\mathrm{NTR}}$-positive cells by qPCR, indicating that BDNF acted to increase neuron number via $\mathrm{p} 75^{\mathrm{NTR}}$ alone. Although NT3 was not examined in this study, it is possible that in vivo the pan-neurotrophin receptor $\mathrm{p} 75^{\mathrm{NTR}}$ on SVZ precursor cells could be activated by any of the neurotrophin ligands to promote neuroblast formation.

Our results provide the first in vivo evidence that $\mathrm{p} 75^{\mathrm{NTR}} \mathrm{ex}-$ pression and signaling are important in regulating the normal level of neurogenesis occurring in the adult SVZ. In the absence of p $75^{\mathrm{NTR}}$, there was a $25-45 \%$ reduction in the number of PSANCAM-positive neuroblasts present in the SVZ and a significant reduction in olfactory bulb weight, particularly in mature adults. Because SVZ precursor cells are responsible for adult neurogenesis in the olfactory bulb, and neuroblast generation is significantly impaired in p $75^{\mathrm{NTR}-1-}$ mice, the reduction in olfactory bulb weight is likely to be a direct result of the reduction in p $75^{\mathrm{NTR}}$-mediated neurogenesis. Thus, this result further supports the idea that regulation of precursor commitment by p $75^{\text {NTR }}$ signaling in the SVZ is physiologically important for the ongoing generation of olfactory bulb neurons.

Although it is unclear to what extent physiological neurotro- 
phin levels vary in the SVZ, and therefore how dynamically neurogenesis might be being regulated by $\mathrm{p} 75^{\mathrm{NTR}}$ activation, these findings provide a mechanism to explain the increase in the number of newly born neurons observed in vivo after exogenous BDNF treatment (Zigova et al., 1998; Benraiss et al., 2001; Pencea et al., 2001; Lee et al., 2002; Chmielnicki et al., 2004). Recently, we have also shown that BDNF has a similar action on progenitor cells from the adult hippocampus (Bull and Bartlett, 2005). Because these hippocampal progenitors are incapable of selfrenewal, this suggests that there is either a latent stem cell population in this region or that a population of stem cells is continually repopulating the hippocampus. The BDNFresponsive $\mathrm{p} 75^{\mathrm{NTR}}$-positive stem cells that we have characterized in this study are likely candidates for the latter possibility.

We have identified a persisting population of cells, within the newborn and adult SVZ stem cell niche, based on the expression of $\mathrm{p} 75^{\mathrm{NTR}}$. This marker provides a means of identifying and purifying an in vivo precursor cell population. It also provides the first functional link between precursor cells and neurogenesis, given its necessity for the maintenance of normal neurogenesis under basal in vivo conditions. We have further demonstrated that the same population is able to respond to local increases in BDNF by promoting neuroblast generation, a response that has been repeatedly associated with increased BDNF in a variety of environmental and disease states, as well as after antidepressant therapy (Dechant and Barde, 2002; Lee et al., 2002; Coppell et al., 2003; Farmer et al., 2004; Garza et al., 2004). Therefore, p $75^{\text {NTR }}$ activation of SVZ neural precursor cells provides an attractive mechanism by which the neurotrophin ligand BDNF can maintain neurogenesis and thus brain function throughout postnatal life.

\section{References}

Adlard PA, Cotman CW (2004) Voluntary exercise protects against stressinduced decreases in brain-derived neurotrophic factor protein expression. Neuroscience 124:985-992.

Altman J (1966) Proliferation and migration of undifferentiated precursor cells in the rat during postnatal gliogenesis. Exp Neurol 16:263-278

Barrett GL, Georgiou A (1996) The low-affinity nerve growth factor receptor p75NGFR mediates death of PC12 cells after nerve growth factor withdrawal. J Neurosci Res 45:117-128.

Benraiss A, Chmielnicki E, Lerner K, Roh D, Goldman SA (2001) Adenoviral brain-derived neurotrophic factor induces both neostriatal and olfactory neuronal recruitment from endogenous progenitor cells in the adult forebrain. J Neurosci 21:6718-6731.

Bull ND, Bartlett PF (2005) The adult mouse hippocampal progenitor is neurogenic but not a stem cell. J Neurosci 25:10815-10821.

Calza L, Giardino L, Pozza M, Bettelli C, Micera A, Aloe L (1998) Proliferation and phenotype regulation in the subventricular zone during experimental allergic encephalomyelitis: in vivo evidence of a role for nerve growth factor. Proc Natl Acad Sci USA 95:3209-3214.

Cattaneo E, McKay R (1990) Proliferation and differentiation of neuronal stem cells regulated by nerve growth factor. Nature 347:762-765.

Chittka A, Chao MV (1999) Identification of a zinc finger protein whose subcellular distribution is regulated by serum and nerve growth factor. Proc Natl Acad Sci USA 96:10705-10710.

Chittka A, Arevalo JC, Rodriguez-Guzman M, Perez P, Chao MV, Sendtner M (2004) The p75NTR-interacting protein SC1 inhibits cell cycle progression by transcriptional repression of cyclin E. J Cell Biol 164:985-996.

Chmielnicki E, Benraiss A, Economides AN, Goldman SA (2004) Adenovirally expressed noggin and brain-derived neurotrophic factor cooperate to induce new medium spiny neurons from resident progenitor cells in the adult striatal ventricular zone. J Neurosci 24:2133-2142.

Coppell AL, Pei Q, Zetterstrom TS (2003) Bi-phasic change in BDNF gene expression following antidepressant drug treatment. Neuropharmacology 44:903-910.

Coulson EJ, Reid K, Bartlett PF (1999) Signaling of neuronal cell death by the p75NTR neurotrophin receptor. Mol Neurobiol 20:29-44.
Curtis MA, Penney EB, Pearson AG, van Roon-Mom WM, Butterworth NJ, Dragunow M, Connor B, Faull RL (2003) Increased cell proliferation and neurogenesis in the adult human Huntington's disease brain. Proc Natl Acad Sci USA 100:9023-9027.

Dechant G, Barde YA (2002) The neurotrophin receptor p75(NTR): novel functions and implications for diseases of the nervous system. Nat Neurosci 5:1131-1136.

Doetsch F, Garcia-Verdugo JM, Alvarez-Buylla A (1997) Cellular composition and three-dimensional organization of the subventricular germinal zone in the adult mammalian brain. J Neurosci 17:5046-5061.

Doetsch F, Caille I, Lim DA, Garcia-Verdugo JM, Alvarez-Buylla A (1999) Subventricular zone astrocytes are neural stem cells in the adult mammalian brain. Cell 97:703-716.

Doetsch F, Petreanu L, Caille I, Garcia-Verdugo JM, Alvarez-Buylla A (2002) EGF converts transit-amplifying neurogenic precursors in the adult brain into multipotent stem cells. Neuron 36:1021-1034.

Farmer J, Zhao X, van Praag H, Wodtke K, Gage FH, Christie BR (2004) Effects of voluntary exercise on synaptic plasticity and gene expression in the dentate gyrus of adult male Sprague-Dawley rats in vivo. Neuroscience 124:71-79.

Felling RJ, Levison SW (2003) Enhanced neurogenesis following stroke. J Neurosci Res 73:277-283.

Garza AA, Ha TG, Garcia C, Chen MJ, Russo-Neustadt AA (2004) Exercise, antidepressant treatment, and BDNF mRNA expression in the aging brain. Pharmacol Biochem Behav 77:209-220.

Gascon E, Vutskits L, Jenny B, Durbec P, Kiss JZ (2007) PSA-NCAM in postnatally generated immature neurons of the olfactory bulb: a crucial role in regulating p75 expression and cell survival. Development 134:1181-1190.

Giuliani A, D’Intino G, Paradisi M, Giardino L, Calza L (2004) p75(NTR)immunoreactivity in the subventricular zone of adult male rats: expression by cycling cells. J Mol Histol 35:749-758.

Gould E, Tanapat P, Rydel T, Hastings N (2000) Regulation of hippocampal neurogenesis in adulthood. Biol Psychiatry 48:715-720.

Hagihara H, Hara M, Tsunekawa K, Nakagawa Y, Sawada M, Nakano K (2005) Tonic-clonic seizures induce division of neuronal progenitor cells with concomitant changes in expression of neurotrophic factors in the brain of pilocarpine-treated mice. Brain Res Mol Brain Res 139:258-266.

Hashimoto K, Shimizu E, Iyo M (2004) Critical role of brain-derived neurotrophic factor in mood disorders. Brain Res Brain Res Rev 45:104-114.

Ito H, Nakajima A, Nomoto H, Furukawa S (2003) Neurotrophins facilitate neuronal differentiation of cultured neural stem cells via induction of mRNA expression of basic helix-loop-helix transcription factors Mash1 and Math1. J Neurosci Res 71:648-658.

Jin K, Peel AL, Mao XO, Xie L, Cottrell BA, Henshall DC, Greenberg DA (2004) Increased hippocampal neurogenesis in Alzheimer's disease. Proc Natl Acad Sci USA 101:343-347.

Kempermann G (2002) Regulation of adult hippocampal neurogenesisimplications for novel theories of major depression. Bipolar Disord 4:17-33.

Kempermann G, Kuhn HG, Gage FH (1998) Experience-induced neurogenesis in the senescent dentate gyrus. J Neurosci 18:3206-3212.

Lachyankar MB, Condon PJ, Daou MC, De AK, Levine JB, Obermeier A, Ross AH (2003) Novel functional interactions between Trk kinase and p75 neurotrophin receptor in neuroblastoma cells. J Neurosci Res 71:157-172.

Lee J, Duan W, Mattson MP (2002) Evidence that brain-derived neurotrophic factor is required for basal neurogenesis and mediates, in part, the enhancement of neurogenesis by dietary restriction in the hippocampus of adult mice. J Neurochem 82:1367-1375.

Lee KF, Li E, Huber LJ, Landis SC, Sharpe AH, Chao MV, Jaenisch R (1992) Targeted mutation of the gene encoding the low affinity NGF receptor p75 leads to deficits in the peripheral sensory nervous system. Cell 69:737-749.

Levers TE, Edgar JM, Price DJ (2001) The fates of cells generated at the end of neurogenesis in developing mouse cortex. J Neurobiol 48:265-277.

Merson TD, Dixon MP, Collin C, Rietze RL, Bartlett PF, Thomas T, Voss AK (2006) The transcriptional coactivator Querkopf controls adult neurogenesis. J Neurosci 26:11359-11370.

Pencea V, Bingaman KD, Wiegand SJ, Luskin MB (2001) Infusion of brainderived neurotrophic factor into the lateral ventricle of the adult rat leads 
to new neurons in the parenchyma of the striatum, septum, thalamus, and hypothalamus. J Neurosci 21:6706-6717.

Reynolds BA, Weiss S (1992) Generation of neurons and astrocytes from isolated cells of the adult mammalian central nervous system. Science 255:1707-1710.

Reynolds BA, Tetzlaff W, Weiss S (1992) A multipotent EGF-responsive striatal embryonic progenitor cell produces neurons and astrocytes. J Neurosci 12:4565-4574.

Richards LJ, Kilpatrick TJ, Bartlett PF (1992) De novo generation of neuronal cells from the adult mouse brain. Proc Natl Acad Sci USA 89:8591-8595.

Rietze RL, Valcanis H, Brooker GF, Thomas T, Voss AK, Bartlett PF (2001) Purification of a pluripotent neural stem cell from the adult mouse brain. Nature 412:736-739.

Rochefort C, Gheusi G, Vincent JD, Lledo PM (2002) Enriched odor exposure increases the number of newborn neurons in the adult olfactory bulb and improves odor memory. J Neurosci 22:2679-2689.

Rousselot P, Lois C, Alvarez-Buylla A (1995) Embryonic (PSA) N-CAM reveals chains of migrating neuroblasts between the lateral ventricle and the olfactory bulb of adult mice. J Comp Neurol 351:51-61.

Roux PP, Barker P (2002) Neurotrophin signaling through the p75 neurotrophin receptor. Prog Neurobiol 67:203-233.

Seidl K, Erck C, Buchberger A (1998) Evidence for the participation of nerve growth factor and its low-affinity receptor (p75NTR) in the regulation of the myogenic program. J Cell Physiol 176:10-21.

van Praag H, Christie BR, Sejnowski TJ, Gage FH (1999) Running enhances neurogenesis, learning, and long-term potentiation in mice. Proc Natl Acad Sci USA 96:13427-13431.

Weiss S, Reynolds BA, Vescovi AL, Morshead C, Craig CG, van der Kooy D (1996) Is there a neural stem cell in the mammalian forebrain? Trends Neurosci 19:387-393.

Yan Q, Johnson Jr EM (1989) Immunohistochemical localization and biochemical characterization of nerve growth factor receptor in adult rat brain. J Comp Neurol 290:585-598.

Yeo TT, Chua-Couzens J, Butcher LL, Bredesen DE, Cooper JD, Valletta JS, Mobley WC, Longo FM (1997) Absence of p75NTR causes increased basal forebrain cholinergic neuron size, choline acetyltransferase activity, and target innervation. J Neurosci 17:7594-7605.

Zhang R, Zhang Z, Wang L, Wang Y, Gousev A, Zhang L, Ho KL, Morshead C, Chopp M (2004) Activated neural stem cells contribute to strokeinduced neurogenesis and neuroblast migration toward the infarct boundary in adult rats. J Cereb Blood Flow Metab 24:441-448.

Zigova T, Pencea V, Wiegand SJ, Luskin MB (1998) Intraventricular administration of BDNF increases the number of newly generated neurons in the adult olfactory bulb. Mol Cell Neurosci 11:234-245. 